\title{
EFFECT OF BOND CHARACTERISTICS AND MACROECONOMIC FACTORS ON THE RETURN OF CORPORATE BONDS IN THE SECTOR OF PROPERTY, REAL ESTATE AND BUILDING CONSTRUCTION
}

\author{
Pratama Dhony ${ }^{*}$, Hartoyo Sri, Maulana Tubagus Nur Ahmad \\ School of Business, Bogor Agricultural University, Indonesia \\ *E-mail: dhonypratama13@gmail.com
}

\begin{abstract}
The purpose of this research is to examine the effect of characteristics of bonds on the bond characteristics on the return of bonds in the sector of property, real estate, and building construction in 2013-2016. This research also aims to find out the relationship of macroeconomic factors to bond return in the sector of property, real estate, and building construction in 2013-2016. Data processing and analysis in this research use the panel data regression techniques. The data used are secondary data selected using purposive sampling with the bonds criteria issued by companies from the property, real estate and building construction sectors which are actively registered during the 2013-2016 period and not yet due, and the bonds ratings are listed in the Pefindo. The research results stated that duration has a positive effect on returns in the property, real estate, and building construction sector. Macroeconomics variable is: inflation and interest rate have a negative effect on bond return in property, real estate, and building construction sector. Other macroeconomic variables are: the exchange rate and IHSG have no effect on bond return. The price of gold as a substitution investment of bonds has a positive effect on bond return in property, real estate, and building construction sector. However, the world's oil prices have no effect on returns.
\end{abstract}

\section{KEY WORDS}

Bond, bonds characteristic, bond return, macroeconomics.

Bond trading continues to increase every year. Bond trade frequency continues to increase from 2013 to 2016. In 2013, the bond trading frequency was recorded as many as 19.989 and then increased to 22.152 in 2014 and continue to increase until 2016 of 24.398.

The property sector which includes construction and real estate sector is one of the important sectors because it is able to attract and encourage activities in various economic sectors, influence the development of the financial sectors, and impacts on the economic growth and employment. The results of the review by the Ministry of Dinance in 2016 showed that within the last five years, the construction and real estate sector in Indonesia experience good growth despite the slowing growth trend, in line with the slowing down of national economic growth. The growth of the property, real estate, and construction sectors are in the top three positions after the sectore of basic industry and chemicals and financial sector, which amounted to $76.23 \%$. The outstanding value of the property, real estate, and construction sector is at 22.20 bilion rupiah, which is the secod highest after the financial sector. The high outstanding value and growth of corporate bonds in the property, real estate, and construction sectore is caused by the new policy by the government.

Paisam (2012) stated that there are several factors influencing bond returns, namely the bonds characteristics, the internal and external factor of the company. One of the characteristics considered by investors is the age of bonds and bond ratings. Widoatmodjo (2007) stated that in the investment analysis in bonds, the investor also needs to perform a fundamental and mroeconomic analysis. The macroeconomic analysis includes calculated monetary developments, circulated money, inflation, exchange rates, interest rates, world oil prices and gold prices. Corporate bonds trading is also affected by market conditions and global sentiment. When the bond price increases, the stock price increases as well. Based on the above description, it is necessary to analyze bond characteristics and macroeconomic 
factors on the bond returns of property, real estate, and building construction sectors, so that inventors can choose bonds that provide high returns.

\section{METHODS OF RESEARCH}

Data processing and analysis in this research used a panel data regression technique. Pane data were collected in cross section and followed during a certain period/time series. Cross section data were collected at a certain time, while time series data were collected from time to time. The model is as follows:

$$
\begin{gathered}
Y_{i t}=\alpha+\beta_{1} X_{1 i t}+\beta_{2} X_{2 i t}+\beta_{3} X_{3 i t}+\beta_{4} X_{4 i t}+\beta_{5} X_{5 i t}+\beta_{6} X_{6 i t}+\beta_{7} X_{7 i t} \varepsilon \\
\text { Hypothesis: } \beta_{1 ;} \beta_{2} ; \beta_{6} ; \beta_{7}>0 ; \beta_{3} ; \beta_{4} ; \beta_{5}<0
\end{gathered}
$$

Where: $\mathrm{i}: \mathrm{n}$ obilagtion; $\mathrm{t}: \mathrm{n}$ observation period; $\alpha$ : Intercept; $\beta$ : independent variable regression coefficient (slope); $Y$ : return; $\mathrm{X}_{1}$ : duration (time); $\mathrm{X}_{2 \text { : }}$ Exchange rate (nominal); $\mathrm{X}_{3}$ : Interest rate (persen); $\mathrm{X}_{4}$ : Inflation (persen); $\mathrm{X}_{5}$ : IHSG; $\mathrm{X}_{6}$ : Gold Price (nominal); $\mathrm{X}_{7}$ : Oil price (nominal); $\varepsilon$ : error.

\section{RESULTS AND DISCUSSION}

Descriptive statistical analysis describes the character of research variables including returns, duration, exchange rates, interest rates, inflation, IHSG, gold price, and oil price. Descriptive statistical analysis contains information about the number of observations, maximum values, minimum values, mean, and standard deviation. The distribution of variable data in this research is presented in Table 1 below.

Table 1 - Data distribution of independent and dependent variables

\begin{tabular}{lllllllll}
\hline & Return & duration & Exchange rate & Interest rate & Inflation & IHSG & Gold Price & Oil price \\
\hline Mean & 0.0065 & 4.273 & 12,425 & 1.715 & 1.370 & 4861.34 & 1243,27 & 70,17 \\
Median & 0.0074 & 4.064 & 12,719 & 1.875 & 1.060 & 4894.61 & 1217,15 & 56,60 \\
Maximum & 0.2587 & 5.573 & 14,657 & 1.938 & 4.430 & 5518.67 & 1594,80 & 105,37 \\
Minimum & -0.1097 & 3.475 & 9,720 & 1.188 & -0.430 & 4223.91 & 1060,30 & 37,04 \\
Std. Dev & 0.0426 & 0.586 & 1,324 & 0.244 & 1.292 & 403.006 & 121,91 & 26,77 \\
Observation & 176 & 176 & 176 & 176 & 176 & 176 & 176 & 176 \\
\hline
\end{tabular}

Table 1 shows the number of data values owned by each variable of 176 data. Return variable has a mean value of 0.0065 with the highest value is 0.2587 and the lowest value is -0.1097 . The mean of bond returns of property, real estate, and building construction sectors is 0.0065 which means that the mean bond return of property, real estate, and building construction sector from a total of 176 data is 0.0065 for the 2013-2016 period. The standard deviation of bond return variable on property, real estate and building construction sector is. 0426 which means that the mean of bond return variation on property, real estate and building construction sectors in the observation year deviates from its mean of 0.0426 .

Variable analysis describes the relationships that occur between variable movements with bond returns. Correlation coefficient aims to find the relationship value between the two variables, whether they are related or not. The negative and positive values illustrate the relationship of influence that occurs between two variable. Positive correlation coefficient value illustrates that the relationship occurs in the same direction, while a negative correlation coefficient illustrates that the relationship occurs between two variables is in the opposite direction. Significance tests aim to see whether the relationship between variables has a significant effect or not. If the regression value is less than 0.05 it shows that the relationship between variables has a significant effect.

Rahardjo (2003) explains that the longer the bonds life, the higher the yield rate given, this is a consequence of the potential risks that may arise due to the length of the bond maturity period. Coupons, durations, and maturity can be seen in table 2 . 
Table 2 - Coupon level, duration and maturity

\begin{tabular}{|c|c|c|c|c|c|c|}
\hline & Kode Obligasi & Kupon (\%) & Durasi (tahun) & Jatuh Tempo (tahun) & Issue Date & Mature Date \\
\hline 1 & ADHI01ACN1 & 9.35 & 3.91 & 5 & 3 Jul 12 & 3 Jul 17 \\
\hline 2 & ADHI01ACN2 & 8.1 & 4.06 & 5 & 15 Mar 13 & 15 Mar 18 \\
\hline 3 & ADHI01BCN1 & 9.8 & 5.22 & 7 & 4 Jul 12 & 4 Jul 19 \\
\hline 4 & ADHI01BCN2 & 8,5 & 5.42 & 7 & 18 Mar 13 & 18 Mar 20 \\
\hline 5 & ADHISM1CN1 & 9,35 & 3.91 & 5 & 3 Jul 12 & 3 Jul 17 \\
\hline 6 & ADHISM1CN2 & 10 & 4.85 & 5 & 15 Mar 13 & $15 \operatorname{Mar} 18$ \\
\hline 7 & BSDE01BCN1 & 9,25 & 3.92 & 5 & 5 Jul 12 & 5 Jul 17 \\
\hline 8 & MDLN02B & 11 & 3.82 & 5 & 27 Des 12 & 27 Des 17 \\
\hline 9 & PTPP01CN1 & 8.375 & 4.05 & 5 & 19 Mar 13 & 19 Mar 18 \\
\hline 10 & SSIA01B & 9.3 & 3.95 & 5 & 6 Nov 12 & 6 Nov 17 \\
\hline 11 & WSKT02B & 9.75 & 3.84 & 5 & 5 Jun 12 & 5 Jun 17 \\
\hline
\end{tabular}

The table shows that the value of the coupon in property, real estate, and building construction bonds ranged from $8.1-11 \%$. The lowest coupon value is owned by bonds with code ADHI01ACN2 of $8.1 \%$, while the highest coupon value is owned by obligation with code MDLN02B of $11 \%$. The duration value correlates with the maturity of the bond. The greater the duration value, the higher the maturity value. The table shows that the variable maturity values range from 5-6 years. The 7-year maturity is held by bonds with a duration of more than 5 years.

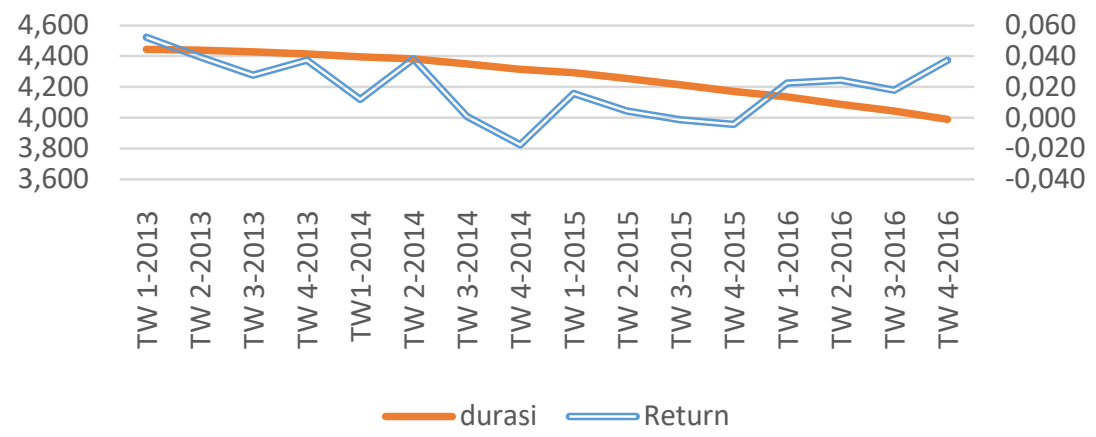

Figure 1 - Duration of movement to return

Figure 1 describes the movement experienced by duration with bond returns. The correlation coefficient occurred between duration with a return is 0.2 . This shows that the correlation that occurs between the duration and return is classified as weak. Positive values indicate that the relationship that occurs between duration and return is in the same direction. The longer the duration, the higher the return generated. The significance test between duration and return resulting in a value of 0.46 . This shows that duration does not affect the return rate.

Based on the calculations performed, the correlation coefficient value between the exchange rate to the bond returns of property, real estate, and building construction sectors is -0.569 . This shows that the correlation between the rupiah exchange rate to dollar with a bond return is categorized as medium correlation relationship. The negative correlation coefficient value shows that the relationship between rupiah exchange rate to dollar with bond return value is inversely proportional. This means that an increase in the rupiah exchange rate to dollar (depreciation) will decrease the bond returns value.

Based on the calculations performed, the correlation coefficient between interest rates and bond returns is $-0.545 ; 0.545$ value shows that the correlation between interest rates and bond returns is categorized as medium correlation. The negative value on the correlation coefficient between the interest rate and the bond return shows that the relationship is inversely proportional. The significance test on the interest rate with a bond return is 0.029 . This explains that interest rates have a significant effect on bond returns. Interest rates affect the high and low yields of bonds, this is because when the interest rates increase, it will relatively reduce the returns received by investors (Ibrahim 2008). Interest rates in the 20132016 are shown in Figure 3. 


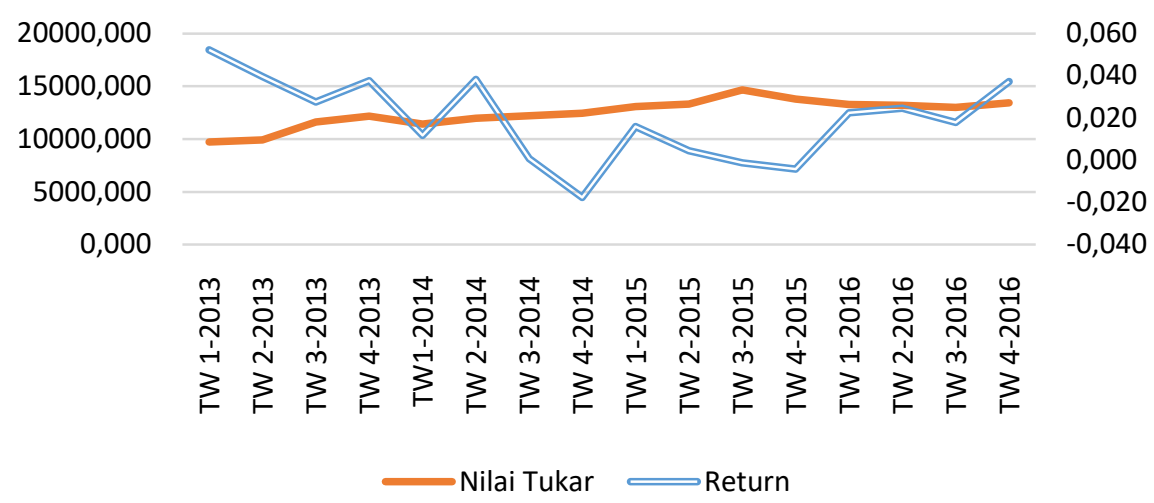

Figure 2 - Movement of exchange rate on return
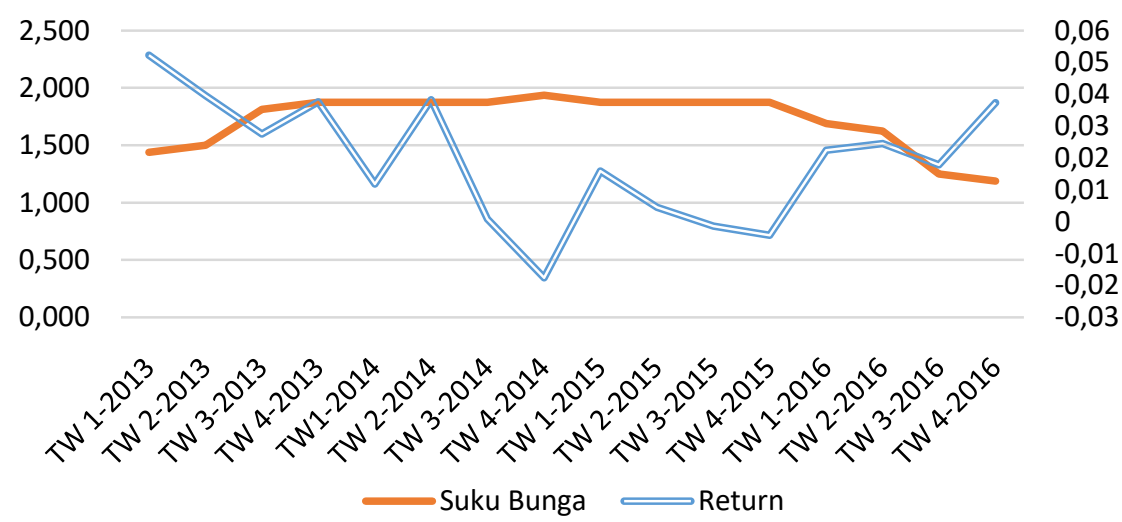

Figure 3 - Interest rate movements on returns

The calculation result of the correlation coefficient between inflation and bond returns is -0.29. The coefficient value between $0.20-0.399$ indicates that the correlation between inflation and bond returns is categorized as a weak correlation. Negative values indicate that the relationship between inflation and bond returns is inversely proportional. This means that increasing inflation will result in a decline in the bond return value, on the contrary, a declining inflation value will result in an increase in the bond returns value. The significance test results of 0.27 state that inflation does not have a significant effect on bond returns. Inflation movements from 2013 to 2016 is shown in the figure below.

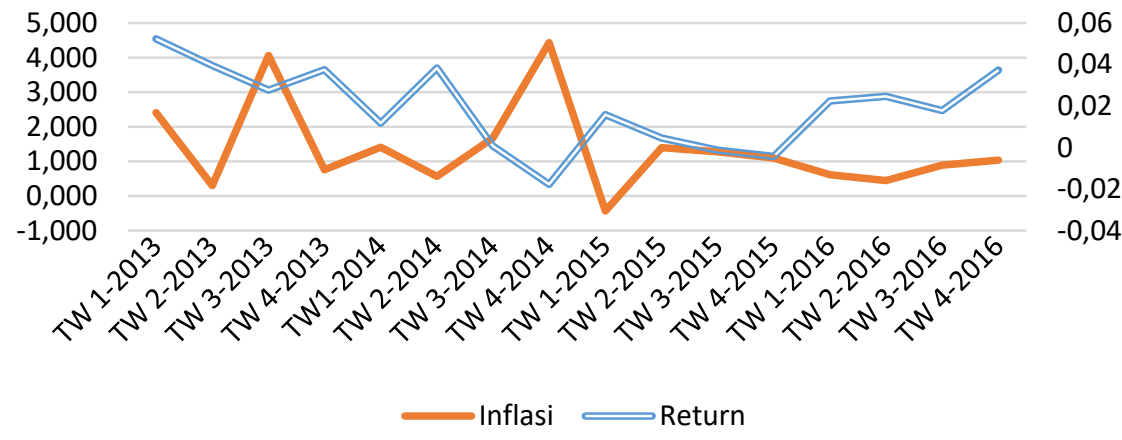

Figure 4 - Inflation movement towards return

The IHSG value and bond return have a negative correlation coefficient of -0.035 . The value of 0.035 shows that the relationship between the IHSG value and bond return is categorized as a weak correlation. Negative values indicate that the relationship correlation of the value 
of the IHSG with a bond return is inversely proportional. This means that an increase in IHSG value will result in a decline in bond returns on property, real estate and building construction sectors. The significant test result is 0.89 . This value states that the IHSG movement does not affect the movement of bond returns. The IHSG value movement and the bond returns of property, real estate, and building construction sectors are shown in Figure 5 below.

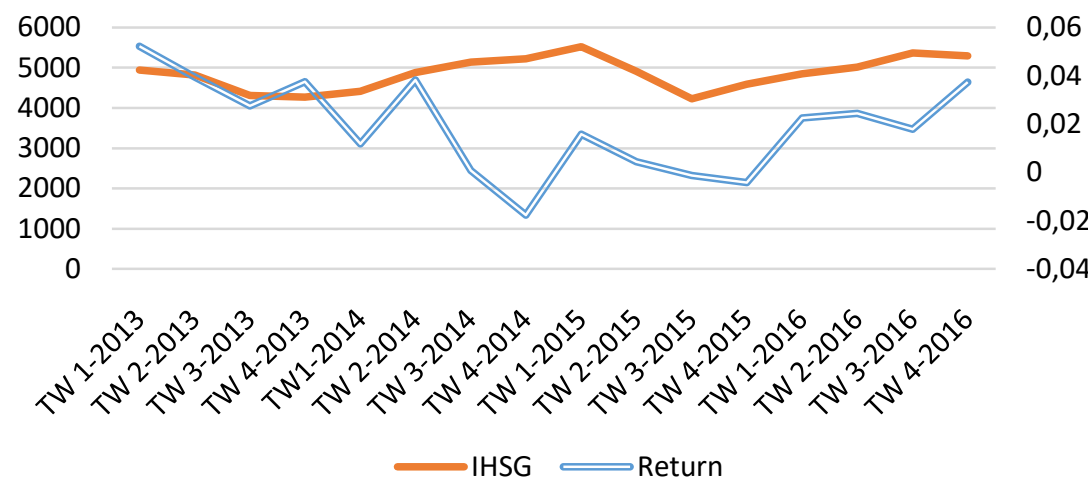

Figure 5 - IHSG movement on return

The gold price correlation coefficient on bond return nn property, real estate and building construction sectors is 0.621 . This value shows that the correlation relationship between the gold price and the bond returns of property, real estate, and building construction sectors is categorized as strong correlation relationships. Positive values indicate that the correlation between the gold price and the return value of bonds in the property, real estate, and building construction sector is directly proportional. This means that an increase in gold prices will result in an increase in the value of bond return on the property, real estate and building construction sectors, and vice versa. The significance test results are 0.01 . It states that the price of gold has a significant effect on bond returns.

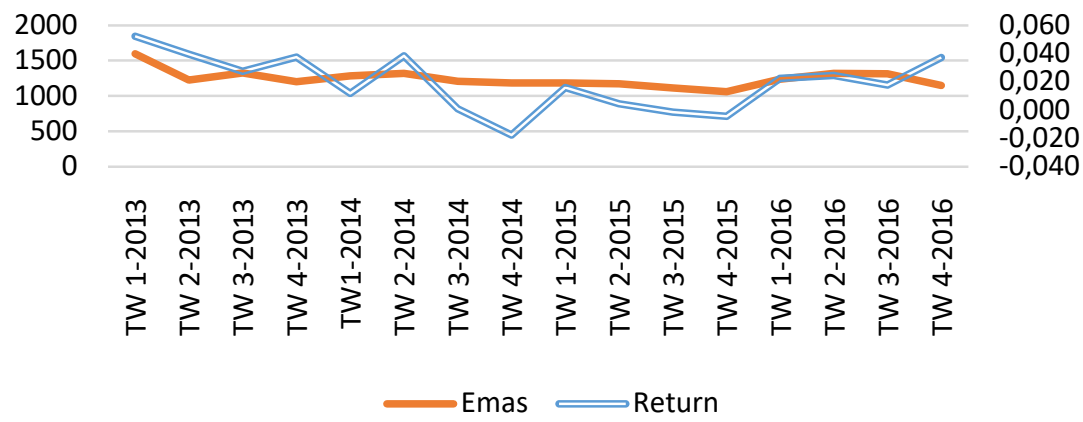

Figure 6 - Movement of gold prices on returns

Based on the calculation results of world oil prices and bond returns the correlation coefficient is 0.504 . It states that the correlation between the world oil price and the bond return value of property, real estate, and building construction sector is categorized as medium correlation relationship. Positive values indicate that the correlation of world oil prices with the bond return value of property, real estate and building construction sectors is directly proportional. This means that an increase in world oil prices will result in an increase in bond returns on property, real estate and building construction sectors, and vice versa. The significance test result is $\mathbf{0 . 0 4}$. This explains that the world oil price has a significant effect on bond returns. The movement of oil prices and bond returns is shown in Figure 7.

The model selection was obtained from the results of the Chow Test and Hausman Test. It shows that the best model to use was the fixed effect model. The results of model testing in this study are shown in Table 3. 


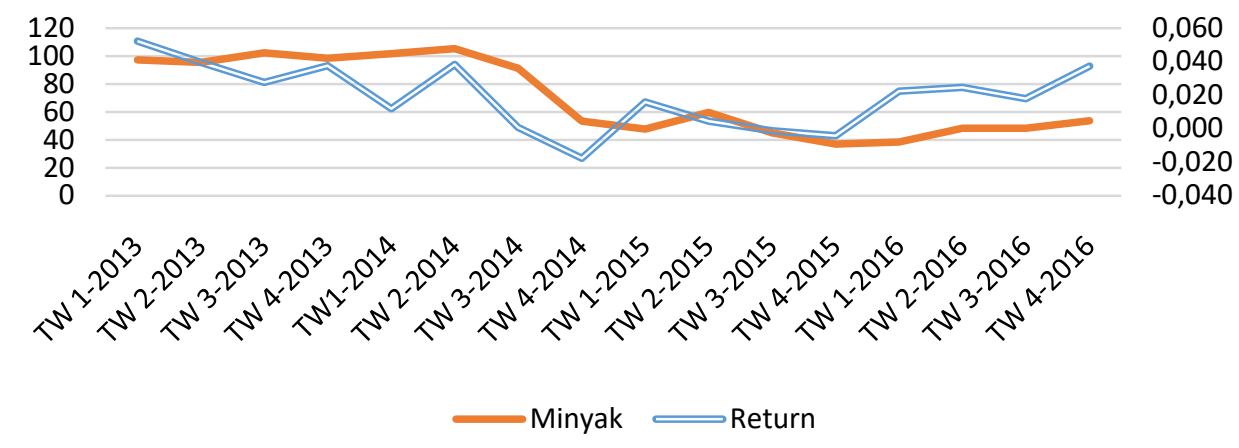

Figure 7 - Movement of oil prices on returns

Table 3 - Factors that determine the return of bonds in the property sector, real estate, and building construction

\begin{tabular}{|c|c|c|c|c|}
\hline Variabel & Coefficient & Std. Error & t-Statistic & Prob. \\
\hline $\mathrm{C}$ & -1.205994 & 0.986846 & -1.222069 & 0.2235 \\
\hline Duration & 0.331767 & 0.172673 & 1.921355 & 0.0232 \\
\hline Exchange Rate & 0.065582 & 0.061226 & 1.071154 & 0.1428 \\
\hline Interest Rate & -0.065170 & 0.020100 & -3.242294 & 0.0007 \\
\hline Inflation & -0.006014 & 0.002230 & -2.696407 & 0.0039 \\
\hline IHSG & -0.042056 & 0.038119 & -1.103285 & 0.1358 \\
\hline Gold price & 0.079166 & 0.042851 & 1.847450 & 0.0333 \\
\hline Oil price & 0.009897 & 0.012930 & 0.765446 & 0.2225 \\
\hline $\mathrm{R}^{2}$ & 0.701298 & Prob (F-st & & 0.0000 \\
\hline
\end{tabular}

The results of the panel data regression show that there are four variables that have a significant effect on bond returns at the five percent rate, namely duration, interest rates, inflation and gold prices. This is explained by a probability value of less than 0.05 . Meanwhile, the exchange rate, IHSG, and oil prices variable do not have a significant effect on the bond returns of property, real estate, and building construction sectors due to the probability value of more than 0.05 . The number of cross sections (i) and time series (t) are 11 bonds and 16 months, respectively.

The research results show the duration variables have a positive significant effect on bond returns with a probability of 0.0232 at the a level of 5 percent and the coefficient of 0.331 . The direction of the duration variable coefficient has a positive value which is in line with the research by Herlambang (2015) which showed that the duration variable has a significant positive effect on bond returns in the banking subsector. However, research by Gebhardt et al. (2003) showed that duration significantly affects bond returns and has a negative relationship direction.

The research results showed that the interest rate variable has a significant negative effect on the bond return value of property, real estate, and building construction sectors. This is explained by a probability value of less than 0.05 which is 0.0007 . Interest rate variable coefficient value is -0.0655 . This shows that the relationship of the effect of interest rates on the bond returns of property, real estate, and building construction sectors is inversely proportional. This means that an increase in interest rates will reduce the bond returns value of property, real estate and building construction sector.

The research results showed that inflation has a significant negative effect on the return bond with a probability of 0.0039 at the a level of 5 percent and the coefficient of 0 0.0060 . The negative coefficient indicates that the effect of inflation on bond returns is in the opposite direction. This means that an increase in inflation will result in declining bond returns. Razali (2011) states that an increase in inflation causes excessive demand for goods as a whole and increasing prices in the economy of a region. This leads the company that issues bonds to issue higher operational costs.

The research results showed that gold price variable has a significant positif effect on the return bond. This states that changes in gold prices will have an impact on bond returns. 
The coefficient result of the effect of gold prices on bond returns is 0.079 . The positive value on the coefficient shows that the effect of the gold price is directly proportional to the bond return. This means that an increase in gold prices will result in an increase in bond returns. The results of this research are in line with the research conducted by Lucey (2010) which shows that the gold price has a significant positive effect on the value of the bonds. Gold trading which is also a long-term investment can be an investor's choice because gold can provide a hedge against inflation.

The research results showed that the rupiah exchange rate has no effect on the bond return. The exchange rate variable shows statistic results with a probability of 0.2857 and coefficient of 0.0655 . Fahmi (2012) stated that when the rupiah weakens against dollar, one policy performed by Bank Indonesia is withdrawing the amount of rupiah distributed in the market. For example, by selling bonds to people, increasing the saving rate so that people are interested to save their money in the bank.

Variable of IHSG and world's oil price have no effect on return. This shows that the bond returns of property, real estate, and building construction sectors in the period are not affected by the IHSG. Research by Hastin (2013) stated that IHSG significantly affects the demand for bonds and the direction is negative. When the IHSG increases, the demand for bonds will decrease, and vice versa, when the IHSG decrease, the demand for bonds will increase. This shows that IHSG has no effect on bond returns but on bond demand instead.

\section{MANAGERIAL IMPLICATIONS}

Investors who want to receive a high return can see the characteristics of the bonds and the occuring macroeconomic factors. The longer the duration and the higher coupons on the bonds purchased, the return will also increase. The research results can also be used as a consideration on to what extent higher interest rate changes affect the returns level obtained. When interest rates decline, investors should buy bonds because the returns obtained will increase.

The occurring inflation factors will also affect the returns that investors will receive in bond investing, the research results show that high inflation will reduce the rate of return, so investors should choose a property, real estate, and building construction bonds in low and stable inflation. The price of gold which is another choice of investment will also affect the return of property, real estate and building construction bonds. The increasing price of gold will have a positive effect on the increase of bond returns because investors are interested in investing in stable macroeconomic factors.

\section{CONCLUSION AND RECOMENDATIONS}

Based on the research results and statistic analysis in the previous chapter, it can be concluded that:

The bond characteristics variable used is duration, which has a positive effect on the return of property, real estate, and building construction sectors.

Macroeconomics variables are inflation and interest rate which have a negative effect on the return of property, real estate, and building construction sectors bonds. Other macroeconomic variables are the exchange rate and IHSG, which have no effect on bond return.

The gold price as substitution investment from the bond positively affects the bond returns of property, real estate, and building construction sectors. However, the world's oil price has no effect on return.

\section{SUGGESTIONS}

Further research is expected to lengthen the research period on similar or different sector towards the variables concluded in this research. Therefore, there will be different expectations of research results. Additionally, other additional variables of finance 
performance (interest coverage, cash flow to sufficiency, and DER) can be used as an alternative in further research on the factors that affect the bond returns such the condition of the company observed.

\section{REFERENCES}

1. Fahmi I. 2012. Manajemen Investasi Teori dan Soal Jawab. Jakarta (ID): Salemba Empat.

2. Gebhardt WR, Hvidkjaer S, Swaminathan B. 2003. The cross-section of expected corporate bond returns: Beats or characteristics? Finance Economic. 75(1);85-114.

3. Herlambang R. 2015. Analisis Karakteristik Obligasi terhadap Return Obligasi pada Sub Sektor Perbankan Tahun 2010-2013 [tesis]. Bogor (ID): Institut Pertanian Bogor.

4. Ibrahim H. 2008. Pengaruh tingkat suku bunga, peringkat obligasi, ukuran perusahaan dan DER terhadap yield to maturity obligasi korporasi di Bursa Efek Indonesia periode tahun 2004-2006 [tesis]. Semarang (ID): Universitas Diponegoro.

5. Lucey BM. 2010. Is Gold a Hedge of Safe Haven? An Analysis of Stocks, Bonds and Gold. The Financial Review. 45(2010): 217-229.

6. Paisarn W. 2012. The Determinants of Thailand Bond Yield Spreads. Working Paper School of Economics and Finance. Curtin University.

7. Rahardjo M. 2009. Ekonomi Moneter. Surakarta (ID): UNS Press.

8. Razali. 2011. Analisis Pengaruh Inflasi, Nilai Tukar Rupiah dan Indeks Dow Jones Terhadap Pergerakan Indeks Harga Saham Gabungan (IHSG) di Bursa Efek Indonesia (BEI) [tesis]. Medan (ID): Sekolah Pascasarjana Universitas Sumatra Utara Medan.

9. Widoatmojo S. 2007. Cara Benar Mencapai Puncak Kemakmuran Finansial Ala Robert T Kiyosaki. Jakarta (ID): Elex Media Komputindo. 